\title{
Composition and Diversity of Areas Under Restoration Process From the Brazilian Atlantic Forest
}

\author{
Marília Isabelle Oliveira da Silva ${ }^{1}$, Luiz Carlos Marangon ${ }^{1}$, Ana Lícia Patriota Feliciano ${ }^{1}$ \\ $\&$ Marilia Alves Grugiki ${ }^{1}$ \\ ${ }^{1}$ Postgraduate Program in Forestry Science, Rural Federal University of Pernambuco, Recife, Pernambuco, \\ Brazil \\ Correspondence: Marília Isabelle Oliveira da Silva, Postgraduate Program in Forestry Science, Department of \\ Forestry Science, Rural Federal University of Pernambuco, Recife, Pernambuco, Brazil. Tel: 55-819-8837-9780. \\ E-mail: marilia.iosilva@gmail.com
}

Received: March 12, 2019

doi:10.5539/jas.v11n9p154

\author{
Accepted: April 22, $2019 \quad$ Online Published: June 30, 2019 \\ URL: https://doi.org/10.5539/jas.v11n9p154
}

\begin{abstract}
The evaluation of the forest restoration scenario is of great importance, with floristic composition and diversity being among the most used ecological variables as indicators. This research aimed to identify the current situation, in terms of species composition and diversity, of two riparian forests under restoration based on a reference ecosystem, the Brazilian Atlantic Forest. Twenty permanent plots $\left(250 \mathrm{~m}^{2}\right)$ were located in areas under restoration process (AR1 and AR2) and in a forest fragment of the region which served as a reference ecosystem (ER). We sampled, identified and classified all tree individuals with $\mathrm{CBH} \geq 15.0 \mathrm{~cm}$ in each plot. Aiming to understand species richness and diversity, besides the traditional indexes (Shannon and Simpson), we also estimated the effective numbers of Hill's diversity ( $\mathrm{qD}=0,1$ and 2 ) considering rarefaction $(\mathrm{P} \leq 0.05)$; and to detect floristic similarities among the study areas we performed a Principal Coordinate Analysis (PCoA). We found dissimilarity among ARs and ER, and the presence of exotic species, indicating that, as recommended, such reference should have been taken into account during the planning of the restoration action. Considering the effective numbers of species (qD) we found differences between the areas, species richness and diversity was higher in ER > AR2 > AR1. We also show that among the restoration areas, with the same age and submitted to the same conditions, AR2 has features that allow us to conclude that this area has a bigger chance of success in the restoration process. However, aiming environmental sustainability, we suggest that some corrective actions should be taken in order to favour the reestablishment of ecological processes in these areas.
\end{abstract}

Keywords: corrective actions, ecological indicators, floristic similarity, monitoring, recovery

\section{Introduction}

Tropical forests globally account for about two-thirds of the species, being irreplaceable for maintaining biodiversity, providing ecosystem services, and mitigating climate change (Gardner et al., 2010). However, the gradual decline of these forests has been observed due to the loss, fragmentation and degradation of ecosystems resulting from land-use change for the deployment of agriculture and urban expansion (Gibbs et al., 2010), directing the efforts each for restoring degraded ecosystems (Aronson et al., 2007; Chazdon, 2008; Holl \& Aide, 2011).

Riparian forests are among the most threatened ecosystems and play an important role in maintaining the ecological balance of water bodies, since they act as filters, ecological corridors and protect the soil against erosive processes (Ávila et al., 2011; Martins, 2014). For Brazilian Atlantic Forest, mainly in the riparian areas, restoration by planting seedlings has increased in the last decades, due to legal laws requirements, providing a growing opportunity for the study of successional trajectories (Rodrigues et al., 2009; Castro et al., 2012). According to Suganuma and Durigan (2014), forest restoration by planting trees usually accelerates the succession process, however, trajectories towards reference ecosystems are rarely evaluated.

By taken restoration actions, it is expected that such forests formed will be self-sustaining and resilient to disturbances (Ruiz-Jaen \& Aide, 2005; Morimoto et al., 2006), however, it is still unknown whether such restorations will actually produce mature native forests (Oldfield et al., 2013). Therefore, it is important to carry out studies that evaluate the actions made and to identify whether such environments are becoming 
self-sustaining or whether they need corrective actions to support this process (Benayas et al., 2009; Dey \& Schweitzer, 2014). In the evaluation of restoration, besides using ecological indicators, the Society for Ecological Restoration (2004) recommends the use of a reference ecosystem as a starting point for evaluation. According to Brancalion et al. (2015), reference ecosystems represent the desired state of the restoration object, considered as the final goal to be achieved.

The floristic composition and diversity are among the most used ecological variables as indicators of the restoration process (Gatica-Saavedra et al., 2017). For decades, studies on diversity in tree species communities were based only on the absolute number of species and the values of indexes with statistical properties were not very accurate (Chao \& Jost, 2012; Chao et al., 2014; Hsieh et al., 2016), which reduced and underestimated the real shape of plant diversity - due to traditional biased methodologies (Colwell et al., 2012). Recently, reformulations have been proposed in the indices and allow for a better understanding of species diversity, giving less importance to rare species (Chao et al., 2014; Gotelli \& Chao, 2013). Although, these indexes were not yet explored in studies focused on restoration areas, they are considered promising for bringing a real idea of the diversity on the environments.

Considering that the evaluation the forest restoration actions is of great importance, the goal of this study was to identify the current situation, in terms of species composition and diversity, of two riparian forests under restoration based on a reference ecosystem, at the Brazilian Atlantic Forest. To do so, we evaluated the floristic composition, taxonomic diversity and floristic similarities among restoration areas and the reference ecosystem. We sought to answer the following questions: (i) Are the vegetation of the areas under restoration part of the natural ecosystem of the region? ii) Do the attributes of diversity and composition indicate the progress of the restoration process in areas with eight years post-planting? With this study we hope to provide important information to encourage workers and researchers to evaluate and disseminate results about forest restoration actions, mainly regarding their ecological benefits.

\section{Method}

This study was developed in three areas located between the towns of Lagoa de Itaenga and Paudalho, at Zona da Mata Norte in the state of Pernambuco, Brazil. The climate classification of the region is type As, according to Köppen-Geiger; the mean annual temperature is $24.2{ }^{\circ} \mathrm{C}$ and the mean annual rainfall is $989 \mathrm{~mm}$ (Alvares et al., 2013). The predominant vegetation in the region is classified as tropical rainforest - seasonal semideciduous forest typology (IBGE, 2012).

In 2008, the planting of seedlings in riparian areas started with the goal of changing these degraded areas into Permanent Preservation Areas (APP). The restoration technique adopted was total plantation of tree species in the total area, at a spacing of $3 \times 3 \mathrm{~m}$, restoring, on average, 6 hectares (ha) of the Engenho Conceição forest (AR1) and 5 ha in the area known as Petribu I (AR2). In the past, AR1 has been used as pasture for animals from neighbouring communities, whereas AR2 has been used as sugar cane plantation.

The Reference Ecosystem (ER) we chose was based on the recommendations of the Society for Ecological Restoration (2004), a forest fragment inserted in the same local context of the areas under restoration, with similar environmental conditions and anthropic pressures. The ER is located between the two ARs, $2.7 \mathrm{~km}$ from the start of AR1 and $1.5 \mathrm{~km}$ from AR2. Important information about these areas are presented in Table 1.

Table 1. Information of the areas under restoration process (AR1 and AR2) and of the reference ecosystem (ER) of the Brazilian Atlantic Forest, in Pernambuco-Brazil

\begin{tabular}{llll}
\hline Features & AR1 & AR2 & ER \\
\hline Geographical coordinates & $7^{\circ} 53^{\prime} 23^{\prime \prime} \mathrm{S}$ & $7^{\circ} 53^{\prime} 16.7^{\prime \prime} \mathrm{S}$ & $7^{\circ} 53^{\prime \prime} 40.8^{\prime \prime} \mathrm{S}$ \\
& $35^{\circ} 13^{\prime} 16.3^{\prime \prime} \mathrm{W}$ & $35^{\circ} 15^{\prime} 9^{\prime \prime} \mathrm{W}$ & $35^{\circ} 14.2^{\prime} 35^{\prime \prime} \mathrm{W}$ \\
Total area (ha) & 6.15 & 5.11 & 26.55 \\
Restoration technique & Total planting & Total planting & Natural secondary succession \\
Age (years) & 8 & 8 & $>30$ years \\
Sampling area $\left(\mathrm{m}^{2}\right)$ & 5000 & 5000 & 5000 \\
\hline
\end{tabular}

We carried out an evaluation of the restoration areas (AR1 and AR2) and the reference ecosystem using ecological indicators, making it possible to analyse the composition, diversity and similarity among the 
environments. These indicators were applied in all areas using the same methodology, as suggested by Brancalion et al. (2015).

In the three areas (AR1, AR2 and ER), 20 permanent plots of $10 \times 25$ meters $\left(250 \mathrm{~m}^{2}\right)$ were placed systemically to collect the variables. In 2016, we performed a floristic and phytosociological assay, in which we labelled and identified all tree individuals with circumference at breast height $(\mathrm{CBH}) \geq 15.0 \mathrm{~cm}$. We also measured the circumferences of the trees and estimated their height.

We collected plant material of the individuals and sent it to the Herbarium Sérgio Tavares of the Forest Science Department from the Federal Rural University of Pernambuco for taxonomic identification. The individuals sampled in the floristic assay were related in a floristic list and the species were named and distributed in families according to the Angiosperm Phylogeny Group IV classification system (APG, 2016). Aiming to verify plant scientific names and authors we consulted the List of Species of the Brazilian Flora (Flora do Brasil, 2019) and the database of Botanical Garden of Missouri (http://www.tropicos.org). Following identification, the species were classified according to their origin (native or exotic), we considered as exotic those species that do not occur naturally in the native vegetation of the region (Atlantic Forest).

Aiming to understand species richness and diversity, we estimated the effective numbers of Hill's diversity (Hill, 1973) based on the proposal of Chao et al. (2014). This estimator includes the three measurements of species diversity that are widely used: species richness $(q=0)$, the exponential of the Shannon diversity $(q=1)$ and the Simpson diversity $(\mathrm{q}=2)$ which is also called as number of common species (Chao et al., 2014). This procedure was performed with the aid of the functions of the "iNEXT" package of the R environment (iNterpolation/EXTrapolation) which provides functions for plotting species diversity curves by interpolation and extrapolation (Hsieh et al., 2016).

In addition, we also estimated the Shannon diversity index $\left(\mathrm{H}^{\prime}\right)$ and Simpson index of dominance $\left(\mathrm{C}^{\prime}\right)$, following the same methodology proposed by Brower and Zar (1984), which were calculated in a traditional way. The values obtained from the Shannon and Simpson indices were compared for their significance using Hutcheson t-test (1970) with $95 \%$ probability level. This test provides the difference between the diversity index of two samples in order to detect significant differences between them (Magurran, 1988), making comparisons between two sets of data obtained in the study areas.

For the analysis of species composition, in order to detect the floristic similarity among the areas, we did an exploratory data analysis using the Principal Coordinate Analysis (PCoA), through the Bray-Curtis distance. We measured the significance among groups by Permutational analysis of variance (PERMANOVA) from 999 permutations $(\alpha=0.01)$. The distances of Bray-Curtis and the dissimilarity matrix were calculated using the "vegdist" and "metaMDS" functions, respectively, from the "vegan" package of the R statistical software (Oksanen et al., 2017). All statistical analysis and graphics were performed in the R environment - version 3.4.0 (R Development Core Team, 2017).

\section{Results}

We sampled 164 individuals in the AR1, which were distributed in 23 species: 20 were identified at species level, one at genus level and two at family level (Table 2). The most representative families were Fabaceae, with approximately $34.8 \%$ of the species, Malvaceae and Bignoniaceae (13\%) and Anacardiaceae $(8.7 \%)$. The other families (Euphorbiaceae, Meliaceae, Moraceae, Myrtaceae, Rubiaceae, Sapindaceae and Urticaceae) had only one species $(4.3 \%)$.

We sampled 325 three individuals in the AR2, which were distributed in 31 species: 30 were identified at species level and one at genus level (Table 2). These species were distributed in 15 families: Fabaceae, with the highest amount of species (35.5\%), followed by Anacardiaceae and Bignoniaceae (9.7\%), Annonaceae and Malvaceae $(6.5 \%)$ and others (Chrysobalanaceae, Euphorbiaceae, Lamiaceae, Malpighiaceae, Meliaceae, Myrtaceae, Rhamnaceae, Rubiaceae, Sapindaceae and Urticaceae) that had only one species (3.2\%).

We sampled 675 individuals in the ER, which were distributed in 43 species: 40 were identified at specific level, one at genus level and two at family level. The species were distributed in 23 families: Fabaceae (14\% of species), followed by Bignoniaceae, Erythroxylaceae, Moraceae, Myrtaceae, Rubiaceae and Sapindaceae (7\%), Nyctaginaceae, Rutaceae and Salicaceae (4.7\%). These results showed that in the three areas, the Fabaceae family was the most representative (Table 2). 
Table 2. Tree species found in two restoration areas (AR1 and AR2) and in the reference ecosystem (ER) of the Brazilian Atlantic Forest, in Pernambuco-Brazil

\begin{tabular}{|c|c|c|c|}
\hline \multirow{2}{*}{ Family/Species } & \multicolumn{3}{|c|}{ Individuals number } \\
\hline & AR1 & AR2 & ER \\
\hline \multicolumn{4}{|l|}{ Anacardiaceae } \\
\hline Anacardium occidentale L. & & 3 & \\
\hline Astronium fraxinifolium Schott & & & 5 \\
\hline Mangifera indica $\mathrm{L}$. & & 1 & \\
\hline Schinus terebinthifolius Raddi & 32 & & \\
\hline Spondias mombin L. & & 2 & \\
\hline Tapirira guianensis Aubl. & 1 & & \\
\hline \multicolumn{4}{|l|}{ Annonaceae } \\
\hline Annona montana Macfad. & & 2 & \\
\hline Annona salzmannii A.DC. & & 1 & \\
\hline \multicolumn{4}{|l|}{ Apocynaceae } \\
\hline Tabernaemontana flavicans Willd. ex Roem. \& Schult. & & & 11 \\
\hline \multicolumn{4}{|l|}{ Bignoniaceae } \\
\hline Bignoniaceae 1 & & & 20 \\
\hline Bignoniaceae 2 & & & 6 \\
\hline Handroanthus impetiginosus (Mart. ex DC.) Mattos & 3 & & \\
\hline Handroanthus serratifolius (Vahl) S.Grose & & & 6 \\
\hline Handroanthus sp. & 1 & & \\
\hline Tabebuia aurea (Silva Manso) Benth. \& Hook.f. ex S.Moore & 1 & 1 & \\
\hline Tabebuia rosea (Bertol.) Bertero ex A.DC. & & 11 & \\
\hline Tecoma stans (L.) Juss. ex Kunth & & 1 & \\
\hline \multicolumn{4}{|l|}{ Boraginaceae } \\
\hline Cordia sellowiana Cham. & & & 21 \\
\hline \multicolumn{4}{|l|}{ Capparaceae } \\
\hline Cynophalla flexuosa (L.) J.Presl & & & 10 \\
\hline \multicolumn{4}{|l|}{ Chrysobalanaceae } \\
\hline Licania tomentosa (Benth.) Fritsch & & 3 & \\
\hline \multicolumn{4}{|l|}{ Erythroxylaceae } \\
\hline Erythroxylum passerinum Mart. & & & 3 \\
\hline Erythroxylum simonis Plowman & & & 24 \\
\hline Erythroxylum sp. & & & 25 \\
\hline \multicolumn{4}{|l|}{ Euphorbiaceae } \\
\hline Euphorbia tirucalli $\mathrm{L}$. & & & 1 \\
\hline Jatropha curcas L. & & 2 & \\
\hline Ricinus communis $\mathrm{L}$. & 1 & & \\
\hline \multicolumn{4}{|l|}{ Fabaceae } \\
\hline Albizia polycephala (Benth.) Killip ex Record & & & 48 \\
\hline Anadenanthera colubrina (Vell.) Brenan & & & 7 \\
\hline Adenanthera pavonina $\mathrm{L}$. & 7 & 3 & \\
\hline Bowdichia virgilioides Kunth & & & 3 \\
\hline Clitoria fairchildiana R.A.Howard & 4 & & \\
\hline Enterolobium contortisiliquum (Vell.) Morong & & 7 & \\
\hline Fabaceae 1 & 1 & & \\
\hline Fabaceae 2 & 1 & & \\
\hline Geoffroea spinosa Jacq. & 1 & 33 & \\
\hline Inga cf. capitata Desv. & & 7 & \\
\hline Inga edulis Mart. & 15 & & \\
\hline Inga ingoides (Rich.) Willd. & & 3 & \\
\hline Inga striata Benth. & 24 & & \\
\hline Leucaena leucocephala (Lam.) de Wit & 1 & 14 & \\
\hline Libidibia ferrea (Mart. ex Tul.) L.P.Queiroz & & 6 & \\
\hline Machaerium hirtum (Vell.) Stellfeld & & & 9 \\
\hline Mimosa caesalpiniifolia Benth. & & 9 & \\
\hline
\end{tabular}




\begin{tabular}{|c|c|c|c|}
\hline \multicolumn{2}{|l|}{ Mimosa sp. } & 2 & \\
\hline \multicolumn{2}{|l|}{ Paubrasilia echinata (Lam.) E.Gagnon, H.C.Lima \& G.P.Lewis } & & 18 \\
\hline \multicolumn{2}{|l|}{ Pithecellobium dulce (Roxb.) Benth. } & 15 & \\
\hline \multicolumn{2}{|l|}{ Senna siamea (Lam.) H.S.Irwin \& Barneby } & 1 & \\
\hline \multicolumn{2}{|l|}{ Swartzia pickelii Killip ex Ducke } & & 1 \\
\hline \multicolumn{4}{|l|}{ Hypericaceae } \\
\hline Vismia guianensis (Aubl.) Choisy & & & 2 \\
\hline \multicolumn{4}{|l|}{ Lamiaceae } \\
\hline \multicolumn{2}{|l|}{ Tectona grandis L.f. } & 4 & \\
\hline \multicolumn{2}{|l|}{ Vitex rufescens A.Juss. } & & 7 \\
\hline \multicolumn{4}{|l|}{ Malpighiaceae } \\
\hline \multicolumn{2}{|l|}{ Malpighia emarginata DC. } & 2 & \\
\hline \multicolumn{4}{|l|}{ Malvaceae } \\
\hline Ceiba speciosa (A.St.-Hil.) Ravenna & 3 & 81 & \\
\hline Guazuma ulmifolia Lam. & 1 & & 1 \\
\hline Sterculia foetida $\mathrm{L}$. & 3 & 4 & \\
\hline \multicolumn{4}{|l|}{ Meliaceae } \\
\hline $\begin{array}{l}\text { Azadirachta indica A.Juss. } \\
\text { Trichilia hirta L. }\end{array}$ & 3 & 55 & \\
\hline Trichilia hirta $\mathrm{L}$. & & & 9 \\
\hline \multicolumn{4}{|l|}{ Moraceae } \\
\hline \multicolumn{2}{|l|}{ Artocarpus heterophyllus Lam. } & & 1 \\
\hline \multicolumn{2}{|l|}{ Brosimum guianense (Aubl.) Huber } & & 1 \\
\hline Maclura tinctoria (L.) D.Don ex Steud. & & & 3 \\
\hline Morus nigra $\mathrm{L}$. & 1 & & \\
\hline Myrtaceae & & & \\
\hline Campomanesia dichotoma (O.Berg) Mattos & & & 2 \\
\hline Campomanesia eugenioides (Cambess.) D.Legrand ex Landrum & & & 7 \\
\hline Syzygium cumini (L.) Skeels & 57 & 40 & 1 \\
\hline Nyctaginaceae & & & \\
\hline Guapira laxa (Netto) Furlan & & & 7 \\
\hline Guapira opposita (Vell.) Reitz & & & 63 \\
\hline Phyllanthaceae & & & \\
\hline Margaritaria nobilis L.f. & & & 3 \\
\hline Polygonaceae & & & \\
\hline Coccoloba mollis Casar. & & & 13 \\
\hline Rhamnaceae & & & \\
\hline Ziziphus joazeiro Mart. & & 1 & 5 \\
\hline Rubiaceae & & & \\
\hline Coutarea hexandra (Jacq.) K.Schum. & & & 10 \\
\hline Genipa americana $\mathrm{L}$. & 1 & 4 & 2 \\
\hline Tocoyena brasiliensis Mart. & & & 1 \\
\hline Rutaceae & & & \\
\hline Zanthoxylum monogynum A.St.-Hil. & & & 2 \\
\hline Zanthoxylum rhoifolium Lam. & & & 1 \\
\hline Salicaceae & & & \\
\hline Casearia hirsuta Sw. & & & 15 \\
\hline Casearia sylvestris Sw. & & & 92 \\
\hline Sapindaceae & & & \\
\hline Allophylus edulis (A.St.-Hil. et al.) Hieron. ex Niederl. & & & 108 \\
\hline Cupania impressinervia Acev.-Rodr. & & & 63 \\
\hline Talisia esculenta (Cambess.) Radlk. & 1 & 1 & 37 \\
\hline Urticaceae & & & \\
\hline Cecropia pachystachya Trécul & 1 & 6 & 1 \\
\hline Total & 164 & 325 & 675 \\
\hline
\end{tabular}

Regarding the occurrence of exotic species, we found in the AR1 eight species (35\% of the total), in the AR2 13 species $(42 \%)$ and in the ER only four species $(9 \%)$. Analyzing the exotic in relation to the number of 
individuals, the percentage values increased. In AR1, 46.85\% of individuals were exotic ones (77 of 164 ind.), in AR2 46.77\% (152 of 325 ind.) and in ER only 1.19\% of individuals were exotic of this region (8 of 675 ind.).

Differences in floristic composition among the restoration areas and the reference ecosystem were enough to group the pairs of plots at each level using the Principal Coordinate Analysis (PCoA) (Figure 1). The graph shows: communities close to each other in the graph have similar species composition and abundance; communities distant to each other have distinct species composition and abundance. Moreover, PERMANOVA corroborated these data, because it showed a significant difference between the environments studied (P-value $=$ 0.001) which is also shown by the graphical analysis - taking into account the centroid points and distances, it can be argued that there is no floristic similarity between the restoration areas and the reference ecosystem.

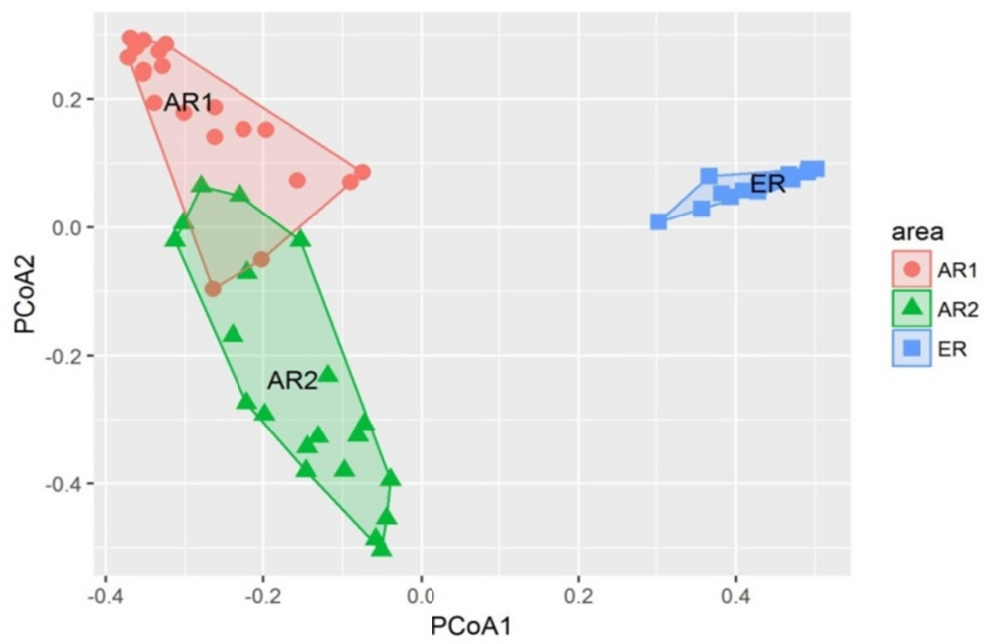

Figure 1. PCoA of tree species sampled in the restoration areas (AR1 and AR2) and in the reference ecosystem (ER) of the Atlantic Forest, Pernambuco-Brazil

Note. The circles, triangles and squares denote the distance estimates ("method" = Bray-Curtis) among the number of individuals of each species within the sample plots in the different areas (AR1, AR2 and ER).

Considering the traditional diversity indexes (Table 3), the Shannon diversity index (H') was higher in the reference ecosystem than in the restoration areas. The Simpson index of dominance (D') followed this same pattern, i.e., it was higher in the ER than in the AR2 and AR1.

Table 3. Diversity indexes estimated for the restoration areas (AR1 and AR2) and the reference ecosystem (ER) of the Atlantic Forest, in Pernambuco-Brazil

\begin{tabular}{llll}
\hline Indexes & AR1 & AR2 & ER \\
\hline Shannon diversity index (H') (nats/ind) & $2.11 \mathrm{~b}$ & $2.56 \mathrm{~b}$ & $2.97 \mathrm{a}$ \\
Simpson index of dominance (D') & $0.81 \mathrm{c}$ & $0.88 \mathrm{~b}$ & $0.92 \mathrm{a}$ \\
\hline
\end{tabular}

Note. * Different letters indicate significant differences $(\alpha<0.05)$; Hutcheson t-test.

The effective numbers of species (qD) or true components of diversity, were for AR1: 23, 8.24 and 5.18 species; for AR2: 31, 12.91 and 8.02 species and for the ER: 43, 19.50 and 12.89 species (orders $\mathrm{q}=0,1$ and 2, respectively). The sampling curve was used for reliable comparisons, starting from any size of an observed sample (interpolation) to twice as many individuals (extrapolated) (Figure 2). The analyses of species richness confirmed that the reference ecosystem was the environment with the largest number of individuals, followed by AR2. The same pattern was observed when diversity components that prioritize species abundance were incorporated $(q=1$ and 2), showing higher diversity in the ER $>$ AR2 $>$ AR1. 

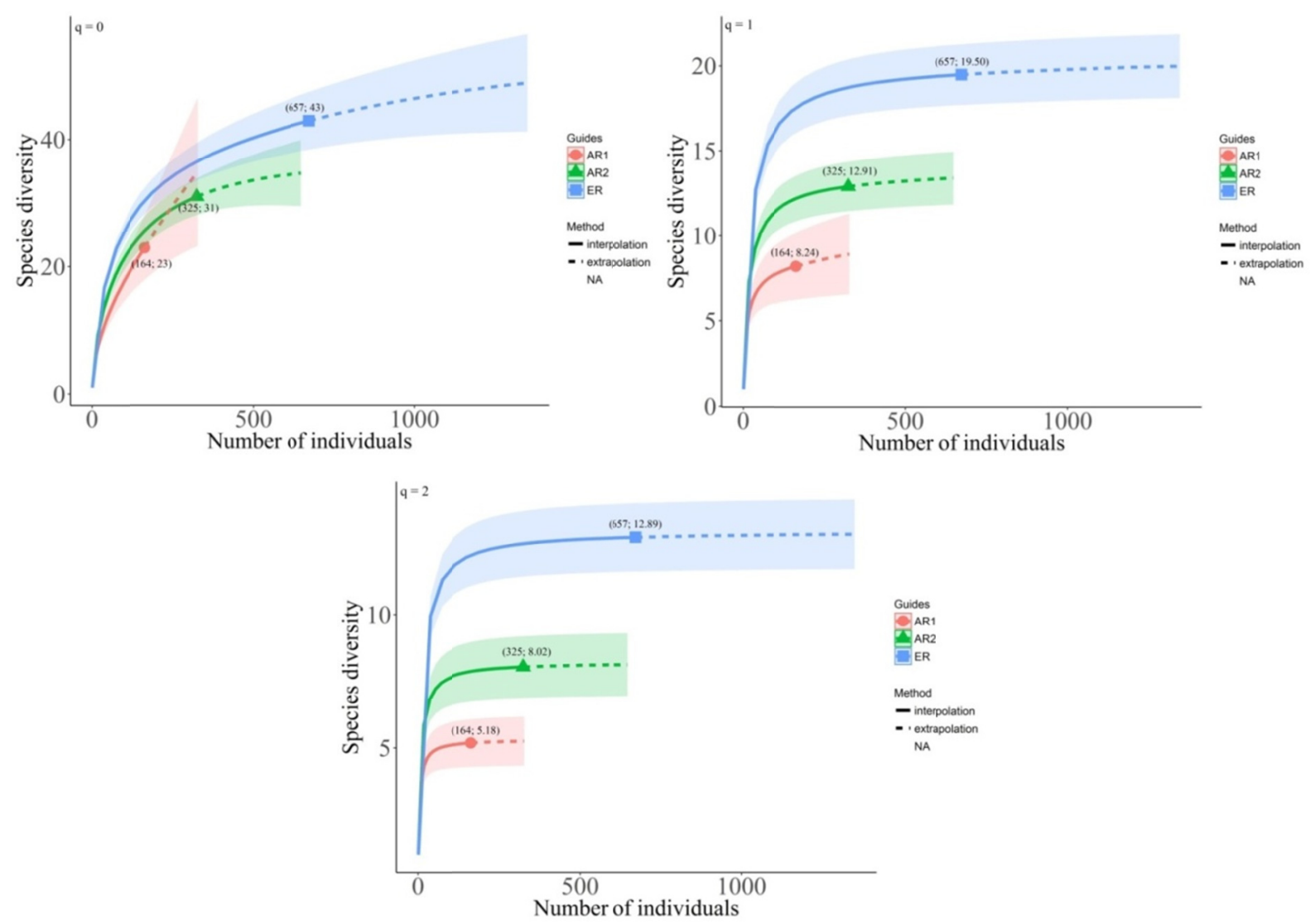

Figure 2. Sample curves by interpolation and extrapolation with $95 \%$ confidence intervals (shaded areas), obtained by the bootstrap method. Data from the tree community: AR1, AR2 and ER are shown separately by diversity profiles with $\mathrm{q}=0$ (species richness, A), $\mathrm{q}=1$ (Shannon diversity, B) and $\mathrm{q}=2$ (Simpson diversity, C)

Note. The solid points, triangles and squares are the mark for the reference samples, and the numbers in brackets are the number of individuals and the effective number of species in each profile ( $\mathrm{qD}=$ Hill numbers in q-order).

Aiming to improve the understanding of the results, we show in Figure 3 the abundance of species in each area. Note that in AR1 only four species are responsible for the majority of the individuals of the community (about $80 \%$ ) which is quite distant from the ER that has a more subtle distribution, with more abundant species. Although the ARs have been implanted at the same time, the individuals in AR2 are more distributed among species than in AR1, showing, a higher potential for sustainability and success. 


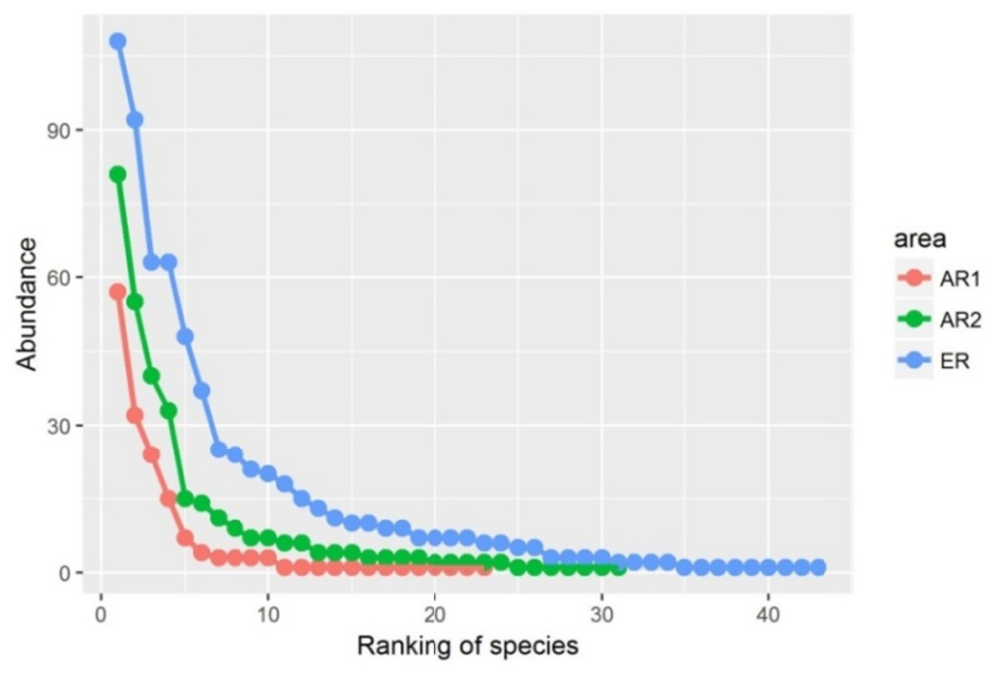

Figure 3. Abundance of species in two restoration areas (AR1 and AR2) and in the reference ecosystem (ER) of the Atlantic Forest, in Pernambuco-Brazil

\section{Discussion}

Regarding the botanical families, Fabaceae is the most predominant family in the three study areas. This family has been found in forest restoration plantations which it is usually the most abundant (Klippel et al., 2015; Silva et al., 2016; Pimentel et al., 2018); favouring plant diversity of the tropical forests, especially in areas of the Atlantic Forest (Zimmermann et al., 2012). Pereira et al. (2013) emphasize the importance of the Fabaceae family in restoration projects, because plants from this family contribute to atmospheric nitrogen fixation, helping in the reestablishment of the soil with increased biological activity and increasing the probability of other trees species, which are less tolerant to stressful conditions, to be found in these areas.

Although the number of exotic species we found in ARs are larger than in the native ecosystem (ER) it is still higher than those observed by Marcuzzo et al. (2014), which studied seven years old restoration areas and found a percentage of exotic species ranging from 17 to $26 \%$. Considering the criteria established by SER (2004), one criteria that deserves attention is the exclusion of exotic species in ecological restoration actions. According to Podadera and Engel (2013), the ecological role of these species in restoration environments as facilitating species seems to decrease over time and in some years, such exotic species can compete with native species delaying and hindering the successional process in the restoration environment. Some studies have shown that when exotic species invade natural environments they can alter plant diversity, nutrient cycling, and to decrease ecosystem services (Powell et al., 2011; Vila et al., 2011; Katsanevakis et al., 2014).

Considering that restoration areas should mirror natural ecosystems (SER, 2004; Rodrigues et al., 2009; Fengler et al., 2017) we can argue that the results found in ARs are not acceptable due to the presence of such exotic species. It is important to identify, eliminate and prevent sowing exotic species because they occupy the niches of native species which can disturb important biotic relationships (Coelho et al., 2014). Thus, it is known that the use of exotic individuals may lead to modifications in the natural systems.

Among the species found in the two restoration environments (AR1 and AR2): Adenanthera pavonina, Azadirachta indica, Cecropia pachystachya, Ceiba speciosa, Genipa americana, Geoffroea spinosa, Leucaena leucocephala, Sterculia foetida, Syzygium cumini, Tabebuia aurea and Talisia esculenta, only four (Cecropia pachystachya, Genipa americana, Syzygium cumini and Talisia esculenta) were present in the three areas evaluated. These results indicate that it is possible that more time is needed to determine the influence of ER in the recovery of the floristic composition of the areas under restoration evaluated in our study. This pattern was also observed by Trujillo-Miranda et al. (2018), which compared a reference ecosystem with areas under different restoration strategies.

It is clear that the floristic composition in AR1 and AR2 areas are different from ER. The differences observed between these areas might be due to several factors, especially because regional species were not selected in the planning of the restoration nor in the planting act. When selecting species for forest restoration is very important 
to consider the composition of the local flora and regional native species, since these species are already adapted to local conditions (Brancalion et al., 2015), increasing the chances of success (Ivanauskas et al., 2007).

Taking into account Shannon and Simpson indices, we can argue that the diversity is higher in ER, followed by AR2 and AR1. When compared to other studies, we showed that the estimated H'values for the study areas are lower than those found for riparian fragments at the same region, which were 3.29 nats / ind. and 3.08 nats / ind. (Hollanda et al., 2010; Oliveira et al., 2009). Regarding the estimated values for Simpson (C), the diversity of plant species in ER was higher than in ARs. Our results are in agreement with aspects previously observed, i.e. showed that difference exists in the floristic composition of the restoration environments and reference ecosystem, which affected the ecological diversity.

When analysing the curve for richness $(\mathrm{q}=0)$ ), it can be observed that in AR1 there was no stabilization (Figure 2a), suggesting that the sampling we used was not enough to stabilize the number of species in the area. However, considering that the sampling was the same for all areas and that AR1 and AR2 are areas with similar ages and conditions, we can conclude that suppression or death of the individuals planted must have had occurred, contributing for loss of diversity, and, consequently, curve destabilization. With the analysis of the other components of diversity ( $q=1$ and 2$)$, we can observe that there is in fact a greater diversity in the ER > AR2 > AR1, corroborating our previous results. Importantly, diversity does not depend exclusively on total density, as highlighted by Santos et al. (2018), when compared two areas in a single environment. In other words, although we found the higher species richness in ER, it does not necessarily mean that ER has the higher diversity. It happened because the reference ecosystem showed a higher distribution of individuals/abundance of species, categorizing ER as an environment with ecological stability, i.e. more tolerant.

The diversity of species in restoration plantations is widely discussed among researchers (Aronson et al., 2010; Salomão et al., 2013; Brancalion et al., 2015; Amazonas et al., 2018). According to Martins (2014), the use of few species in restoration projects, in a scenario with low resilience, can lead to the failure of the process, since pest attacks or repeated degrading actions can eliminate several tree individuals. Brancalion et al. (2010) argue that restoration with a high number of tree species can create different micro-habitats and niches, which will contribute to produce a self-sustaining forest. However, Durigan et al. (2010) argue that searching for a high number of species without planning it can contribute to misidentification of species, genetic contamination and even the extinction of locally rare populations due to failures in the collection of seeds. In fact, the use of more species does not guarantee the success in the restoration process, however, if the goal is to restore the biodiversity of native species in the area, to make use of more species can contribute greatly.

Considering the composition and diversity data evaluated from the indicators presented above, we showed that there is no similarity between the restoration areas and the landscape reference ecosystem, as suggested by SER (2004) and researchers working in this field. With respect to the success of the restoration, we showed that AR2 shows better results of species richness and diversity than AR1, indicating an evolution in the process of forest restoration that has been implemented eight years ago. However, it is important to highlight that other monitoring should be done in order to analyse the reestablishment of ecological functions in long-term environments, as well as the need to embrace corrective actions. As Hotta et al. (2015) suggested, these corrective actions also called as adaptive management are important for the integration of restoration sites with the surrounding vegetation, favouring the process.

\section{Conclusions}

The study of the composition, diversity and floristic similarity of the areas under restoration and the comparison with a reference ecosystem was fundamental to evaluate the effectiveness of the restoration process. The present study showed that the floristic composition of the areas under restoration (AR1 and AR2) were not reflect what was observed in the natural ecosystem (ER), indicating absence of floristic similarity and differences in both species richness and diversity patterns.

Taken into account the areas in restoration, which are of the same age, AR2 was considered the area with higher potential to reach the ER level and, consequently, it has higher chances of success. However, we suggest the continuity of monitoring in the future aiming to investigate the restoration process and that corrective actions be applied, mainly associated with the control of exotic species. These findings infer about the importance of planning restoration actions based on a reference ecosystem, in order to minimize errors. Additionally, it can be assumed that these findings can be utilized used to base future restoration actions in environments similar to the present study. 


\section{References}

Alvares, C. A., Stape, J. L., Sentelhas, P. C., Gonçalves, J. L. M., \& Sparovek, G. (2013). Koppen’s climate classification map for Brazil. Meteorologische Zeitschrift, 22(6), 711-728. https://doi.org/10.1127/ 0941-2948/2013/0507

Amazonas, N. T., Forrester, D. I., Silva, C. C., Almeida, D. R. A., Rodrigues, R. R., \& Brancalion, P. H. S. (2018). High diversity mixed plantations of Eucalyptus and native trees: An interface between production and restoration for the tropics. Forest Ecology and Management, 417, 247-256. https://oi.org/10.1016/ j.foreco.2018.03.015

APG (The Angiosperm Phylogeny Group). (2016). An update of the Angiosperm Phylogeny Group classification for the orders and families of flowering plants: APG IV. Botanical Journal of the Linnean Society, 181(1), 1-20. https://doi.org/10.1111/boj.12385

Aronson, J., Blignaut, J. N., Milton, S. J., Maitre, D. L., Esler, K. J., Limouzin, A., ... Lederer, N. (2010). Are socioeconomic benefits of restoration adequately quantified? A meta-analysis of recent papers (200-2008) in Restoration Ecology and 12 other scientific journals. Restoration Ecology, 18(2), 143-154. https://doi.org/10.1111/j.1526-100X.2009.00638.x

Aronson, J., Milton, S. J., \& Blignaut, J. N. (2007). Restoring natural capital: science, business and practice. Washington, DC: Island Press.

Ávila, A. L., Araujo, M. M., Longhi, S. J., \& Gasparin, E. (2011). Caracterização da vegetação e espécies para recuperação de mata ciliar, Ijuí, RS. Ciência Florestal, 21(2), 251-260. https://doi.org/10.5902/ 198050983229

Benayas, J. M. R., Newton, A. C., Diaz, A., \& Bullock, J. M. (2009). Enhancement of biodiversity and ecosystem services by ecological restoration: A meta-analysis. Science, 325(5944), 1121-1124. https://doi.org/10.1126/science.1172460

Brancalion, P. H. S., Gandolfi, S., \& Rodrigues, R. R. (2015). Restauração florestal. São Paulo, SP: Oficina de Textos.

Brancalion, P. H. S., Rodrigues, R. R., Gandolfi, S., Kageyama, P. Y., Nave, A. G., Gandara, F. B., ... Tabarelli, M. (2010). Instrumentos legais podem contribuir para a restauração de florestas tropicais biodiversas. Revista Árvore, 34(3), 455-470. https://doi.org/10.1590/S0100-67622010000300010

Brower, J. E., \& Zar, J. H. (1984). Field and laboratory methods for general ecology. Boston, MA: W.C.B McGraw-Hill Publishers.

Castro, D., Mello, R. S. P., \& Poester, G. C. (2012). Práticas para restauração da mata ciliar. Porto Alegre, RS: Catarse-Coletivo de Comunicação.

Chao, A., \& Jost, L. (2012). Coverage-based rarefaction and extrapolation: Standardizing samples by completeness rather than size. Ecology, 93(12), 2533-2547. https://doi.org/10.1890/11-1952.1

Chao, A., Gotelli, N. J., Hsieh, T. C., Sander, E. L., Ma, K. H., Colwell, R. K.., \& Ellison, A. M. (2014). Rarefaction and extrapolation with Hill numbers: A framework for sampling and estimation in species diversity studies. Ecological Monographs, 84(1), 45-67. https://doi.org/10.1890/13-0133.1

Chazdon, R. (2008). Chance and determinism in tropical forest succession. In W. P. Carson, \& S. A. Schnitzer (Ed.), Tropical forest community ecology (pp. 384-408). Oxford, Oxfordshire: Wiley Blackwell.

Coelho, G. F., Sousa, R. F. B., Gonçalves Jr, A. C., Correia, A. F., Cordeiro, J., \& Malavasi, U. C. (2014). Aspectos da legislação ambiental para a revegetação de matas ciliares no estado do Paraná. Acta Iguazu, 3(1), 1-13.

Colwell, R. K., Chao, A., Gotelli, N. J., Lin, S. Y., Mao, C. X., Chazdon, R. L., \& Longino, J. T. (2012). Models and estimators linking individual-based and sample-based rarefaction, extrapolation and comparison of assemblages. Journal of Plant Ecology, 5(1), 3-21. https://doi.org/10.1093/jpe/rtr044

Dey, D. C., \& Schweitzer, C. J. (2014). Restoration for the future: Endpoints, targets, and indicators of progress and success. Journal of Sustainable Forestry, 33(Sup1.), S43-S65. https://doi.org/10.1080/10549811. 2014.883999

Durigan, G., Engel, V. L., Torezan, J. M., Melo, A. C. G., Marques, M. C. M., Martins, S. V., ... Scarano, F. R. (2010). Normas jurídicas para a restauração ecológica: Uma barreira a mais a dificultar o êxito das 
iniciativas? Revista Árvore, 34(3), 471-485. https://doi.org/10.1590/S0100-67622010000300011

Fengler, F. H., Bressane, A., Carvalho, M. M., Longo, R. M., Medeiros, G. A., Melo, W. J., ... Ribeiro, A. I. (2017). Forest restoration assessment in Brazilian Amazonia: A new clustering-based methodology considering the reference ecosystem. Ecological Engineering, 108, 93-99. https://doi.org/10.1016/ j.ecoleng.2017.08.008

Flora do Brasil (2019). Flora do Brasil_Jardim Botânico do Rio de Janeiro. Retrieved February12, 2019, from http://floradobrasil.jbrj.gov.br

Gardner, T. A., Barlow, J., Sodhi, N. S. \& Peres, C. A. (2010). A multi-region assessment of tropical forest biodiversity in a human-modified world. Biological Conservation, 143(10), 2293-2300. https://doi.org/ 10.1016/j.biocon.2010.05.017

Gatica-Saavedra, P., Echeverría, C., \& Nelson, C. R. (2017). Ecological indicators for assessing ecological success of forest restoration: a world review. Restoration Ecology, 25(6), 850-857. https://doi.org/10.1111/ rec. 12586

Gibbs, H. K., Ruesch, A. S., Achard, F., Clayton, M. K., Holmgren, P., Ramankutty, N., \& Foley, J. a. (2010). Tropical forests were the primary sources of new agricultural land in the 1980s and 1990s. Proceedings of the National Academy of Sciences, 107(38), 16732-16737. https://doi.org/10.1073/pnas.0910275107

Gotelli, N. J., \& Chao, A. (2013). Measuring and estimating species richness, species diversity, and biotic similarity from sampling data. In S. A. Levin (Ed.), The encyclopedia of biodiversity. New York, USA: Elsevier. https://doi.org/10.1016/B978-0-12-384719-5.00424-X

Hill, M. O. (1973). Diversity and evenness: A unifying notation and its consequences. Ecology, 54(2), 427-432. https://doi.org/10.2307/1934352

Holanda, A. C., Feliciano, A. L. P., Marangon, L. C., Santos, M. S., Melo, C. L. S. M. S., \& Pessoa, M. M. L. (2010). Estrutura de espécies arbóreas sob efeito de borda em um fragmento de floresta estacional semidecidual em Pernambuco. Revista Árvore, 34, 103-114. https://doi.org/10.1590/S0100-676220100 00100012

Holl, K. D., \& Aide, T. M. (2011). When and where to actively restore ecosystems? Forest Ecology and Management, 261(10), 1558-1563. https://doi.org/10.1016/j.foreco.2010.07.004

Hotta, K., Ishii, H., Sasaki, T., Doi, N., Azuma, W., Oyake, Y., ... Yoshida, H. (2015). Twenty-one years of stand dynamics in a 33-year-old urban forest restoration site at Kobe Municipal Sports Park, Japan. Urban Forestry \& Urban Greening, 14(2), 309-314. https://doi.org/10.1016/j.ufug.2015.03.005

Hsieh, T. C., Ma, K. H., \& Chao, A. (2016). iNEXT: An R package for rarefaction and extrapolation of species diversity (Hill numbers). Methods in Ecology and Evolution, 7(12), 1451-1456. https://doi.org/10.1111/ 2041-210X.12613

Hutcheson, K. (1970). A test for comparing diversities based on the Shannon formula. Journal of Theoretical Biology, 29, 151-154. https://doi.org/10.1016/0022-5193(70)90124-4

IBGE (Instituto Brasileiro de Geografia e Estatística). (2012). Manual técnico da vegetação brasileira. Rio de Janeiro, RJ: IBGE.

Ivanauskas, N. M., Rodrigues, R. R., \& Souza, V. C. (2007). The importance of the regional floristic diversity for the forest restoration successfulness. In R. R. Rodrigues, S. V. Martins, \& S. Gandolfi (Eds.), High diversity forest restoration in degraded areas (pp. 63-76). New York, USA: Nova Science Publishers.

Katsanevakis, S., Wallentinus, I., Zenetos, A., Leppäkoski, E., Çinar, M. E., Oztürk, B., ... Cardoso, A. C. (2014). Impacts of invasive alien marine species on ecosystem services and biodiversity: A pan European review. Aquatic Invasions, 9(4), 391-423. https://doi.org/10.3391/ai.2014.9.4.01

Klippel, V. H., Pezzopane, J. E. M., Silva, G. F., Caldeira, M. V. W., Pimenta, L. R., \& Toledo, J. V. (2015). Avaliação de métodos de restauração florestal de Mata de Tabuleiros, ES. Revista Árvore, 39(1), 69-79. https://doi.org/10.1590/0100-67622015000100007

Magurran, A. E. (1988). Ecological diversity and its measurement. New Jersey, USA: Princeton. https://doi.org/ 10.1007/978-94-015-7358-0

Marcuzzo, S. B., Araújo, M. M., Rorato, D. G., \& Machado, J. (2014). Comparação entre áreas em restauração e área de referência no Rio Grande do Sul, Brasil. Revista Árvore, 38(6), 961-972. https://doi.org/ 


\section{$10.1590 / \mathrm{S} 0100-67622014000600001$}

Martins, S. V. (2014). Recuperação de matas ciliares: No contexto do novo código florestal. Viçosa, MG: Aprenda Fácil.

Morimoto, Y., Njoroge, J. B., Nakamura, A., Sasaki, T., \& Chihara, Y. (2006). Role of the EXPO'70 forest project in forest restoration in urban areas. Landsc. Ecol. Eng., 2(2), 119-127. https://doi.org/10.1007/ s11355-006-0007-7

Oksanen, J., Blanchet, F. G., Friendly, M., Kindt, R., Legendre, P., Mcglinn, D., ... Wagner, H. (2017). Vegan: Community Ecology Package. R Package, Version 2.4-4. Retrieved from https:/CRAN.Rproject.org/ package $=$ vegan

Oldfield, E. E., Warren, R. J., Felson, A. J., \& Bradford, M. A. (2013). Challenges and future directions in urban afforestation. Journal of Appleid Ecology, 50, 1169-1177. https://doi.org/10.1111/1365-2664.12124

Oliveira, E. B., Marangon, L. C., Feliciano, A. L. P., Ferreira, R. L. C., \& Rêgo, P. L. (2009). Estrutura fitossociológica de um fragmento de mata ciliar, Rio Capibaribe Mirim, Aliança, Pernambuco. Revista Brasileira de Ciências Agrárias, 4(2), 167-172. https://doi.org/10.5039/agraria.v4i2a8

Pereira, S. R., Laura, V. A., \& Souza, A. L. T. (2013). Establishment of Fabaceae tree species in a tropical pasture: influence of seed size and weeding methods. Restoration Ecology, 21(1), 67-74. https://doi.org/10.1111/ j.1526-100X.2011.00858.x

Pimentel, D. J. O., Feliciano, A. L. P., Marangon, L. C., Silva, M. I. O., Santos, J. N. B., \& Pinto, A. V. F. (2018). The Effect of Different Levels of Inclusion for Forest Restoration Assessment. Journal of Experimental Agriculture International, 23(5), 1-10. https://doi.org/10.9734/JEAI/2018/42016

Podadera, D. S., \& Engel, V. L. (2013). Eliminação de espécie exótica em plantio de Reserva Legal. In G. Durigan, \& V. S. R. Ramos (Eds.), Manejo adaptativo: Primeiras experiências na restauração de ecossistemas (pp. 39-41). São Paulo, SP: Páginas \& Letras Editora.

Powell, K. I., Chase, J. M., \& Knight, T. M. (2011). A synthesis of plant invasion effects on biodiversity across spatial scales. Am. J. Bot., 98(3), 539-548. https://doi.org/10.3732/ajb.1000402

R Development Core Team (2017). A language and environment for statistical computing. Vienna, Austria: R Foundation for Statistical Computing. Retrieved from https://www.R-project.org

Rodrigues R. R., Lima, R. A. F., Gandolfi, S., \& Nave, A. G. (2009). On the restoration of high diversity forests: 30 years of experience in the Brazilian Atlantic Forest. Biological Conservation, 142(6), 1242-1251. https://doi.org/10.1016/j.biocon.2008.12.008

Ruiz-Jaen, M. C., \& Aide, T. M. (2005). Restoration success: How is it being measured? Restoration Ecology, 13(3), 569-577. https://doi.org/10.1111/j.1526-100X.2005.00072.X

Salomão, R. P., Santana, A. C., \& Brienza Júnior, S. (2013). Seleção de espécies da floresta ombrófila densa e indicação da densidade de plantio na restauração florestal de áreas degradadas na Amazônia. Ciência Florestal, 23(1), 139-151. https://doi.org/10.5902/198050988448

Santos, J. N. B.; Medeiros, R. L. S., Santos, T. E. D., Barros, A. P., Oliveira, E. J. B. L., Fernande, F. A. S., ... Barbosa, A. S. (2018). Diversity and Structure of Adult and Regenerating Arbor Component in Forest 'Submontana', Paraíba-Brazil. Journal of Experimental Agriculture International, 25(5), 1-14. https://doi.org/10.9734/JEAI/2018/42854

SER (Society for Ecological Restoration International Science \& Policy Working Group). (2004). The SER International Primer on Ecological Restoration. www.ser.org \& Tucson: Society for Ecological Restoration International. Retrieved from http:/www.ser.org/docs/default-document-library/english.pdf

Silva, K. A., Martins, S. V., Miranda Neto, A., Demolinari, R. A., \& Lopes, A. T. (2016). Restauração Florestal de uma Mina de Bauxita: Avaliação do Desenvolvimento das Espécies Arbóreas Plantadas. Floresta e Ambiente, 23(3), 309-319. https://doi.org/10.1590/2179-8087.142515

Suganuma, M. S., \& Durigan, G. (2014). Indicators of restoration success in riparian tropical forests using multiple reference ecosystems. Restoration Ecology, 23(3), 238-251. https://doi.org/10.1111/rec.12168

Trujillo-Miranda, A. L., Toledo-Aceves, T., López-Barrera, F., \& Fernández-Gerez, P. (2018). Active versus passive restoration: Recovery of cloud forest structure, diversity and soil condition in abandoned pastures. Ecological Engineering, 117, 50-61. https://doi.org/10.1016/j.ecoleng.2018.03.011 
Vila, M., Espinar, J. L., Hejda, M., Hulme, P. E., Jarošík, V., Maron, J. L., .. Pyšek, P. (2011). Ecological impacts of invasive alien plants: A meta-analysis of their effects on species, communities and ecosystems. Ecology Letters, 14(7), 702-708. https://doi.org/10.1111/j.1461-0248.2011.01628.x

Zimmermann, T. G., Begnini, R. M., Castellani, T. T., Lopes, B. C., \& Reis, A. (2012). Consumo e dispersão secundária de sementes de Mucuna urens (Fabaceae) em Floresta Atlântica no Sul do Brasil. Rodriguésia, 63(4), 1139-1145. https://doi.org/10.1590/S2175-78602012000400024

\section{Copyrights}

Copyright for this article is retained by the author(s), with first publication rights granted to the journal.

This is an open-access article distributed under the terms and conditions of the Creative Commons Attribution license (http://creativecommons.org/licenses/by/4.0/). 